\title{
From Binary Narratives to Diversified Tales
}

\author{
Changing the Paradigm in the Study of Dutch Colonial Participation
}

\author{
Cátia Antunes
}

TVGESCH 131 (3): 393-407

DOI: 10.5117/TVGESCH2018.3.001.ANTU

\begin{abstract}
From Binary Narratives to Diversified Tales. Changing the Paradigm in the Study of Dutch Colonial Participation

This article defends the existence of a Dutch empire and that this empire, as all the other empires in Western Europe, fulfilled the goals, interests and necessities of the central state, of the local elites and of the common man. There was thus a societal consensus about, and acceptance of empire. Furthermore, this article claims that the Dutch empire was not only a trading enterprise, as many have claimed, but a territorially expanding state that faced challenges regarding sovereignty, subjection and belonging across the globe, as did all other empires. In the conclusion, I suggest a change of paradigm in approaching the Dutch empire from the point of view of the multiplicity of actors that not only created, participated and developed the empire, but also from the perspective of the ones that actually became the empire.
\end{abstract}

Keywords: Dutch Empire, Dutch East India Company (VOC), Dutch West India Company (WIC), historiography

Dutch maritime expansion overseas has traditionally been studied from two perspectives: firstly by viewing the chartered joint stock companies as modern elements in the European institutional, organizational and economic landscape ${ }^{1}$

1 Femme S. Gaastra, De geschiedenis van de VOC (Zutphen 2003) (new, revised edition); Oscar C. Gelderblom, Abe de Jong and Joost P. B. Jonker, 'The and secondly by focusing on VOC and WIC employees' relationships in the colonial setting with the autochthonous

Formative Years of the Modern Corporation: The Dutch East India Company VOC, 1602-1623, Journal of Economic History 73.4 (2013) 1050-1076; Henk den Heijer, De geoctrooieerde Compagnie. De VOC en de WIC als voorlopers van de naamloze vennootschap (Deventer 2005); Henk den Heijer, De geschiedenis van de WIC (Zutphen 2007). 
communities and new European settlers. $^{2}$

Curiously, Dutch maritime expansion overseas has not generally been seen as synonymous with the Dutch empire, which is even more extraordinary if we consider that already in the Early Modern period other countries regarded the Republic's maritime expansion as empire-building. ${ }^{3}$ In 1642, for example, the Portuguese ambassador in The Hague wrote to King John IV that 'The power of the Company [VOC] and the daring of the West India Company privateers will deprive Your Majesty of wealth and power, for which the Truce [of nine years] is more than justified, for this empire will grow at Your expense and those of Your subjects and domains.' ${ }^{4}$ Only recently have historians acknowledged the

2 Nirmal Ranjith Dewasiri, The Adaptable Peasant. Agrarian Society in Western Sri Lanka under Dutch Rule, 1740-1800 (Leiden 2007); Kerry Ward, Networks of Empire: Forced Migration and the Dutch East India Company (Cambridge 2008); Chiu Hsin-hui, The Colonial 'Civilizing Process' in Dutch Formosa, 1624-1662 (Leiden 2008); Anjana Singh, Fort Cochin in Kerala, 1750-1830. The Social Condition of a Dutch Community in an Indian Milieu (Leiden 2010); Gert Oostindie and Jessica Roitman, 'Repositioning the Dutch in the Atlantic, 1680-180o', Itinerario 26.3 (2012) 129-160; Linda M. Rupert, Creolization and Contraband: Curaçao in the Early Modern Atlantic World (Atlanta 2012); Gert Oostindie, 'Introduction', in: Gert Oostindie and Jessica Roitman ed., Dutch Atlantic Connections, 1680-180o. Linking Empires, Bridging Borders (Leiden 2014) 1-20. 3 The only exception is Charles R. Boxer, The Dutch Seaborne Empire: 1600-1800 (London 1991 re-edition). 4 Nationaal Archief Den Haag (hierna: NL-HaNa), Archief van de Staten Generaal (1.01.02), Liassen Portugal, 7010-1, letter by Francisco Andrade de Leitão to King John IV, 2 August 1642. Original text: 'O poder da Companhia e o atrevimento dos corsários da Companhia das Índias Ocidentais roubarão de Vossa Magestade riqueza e poder, pelo que as Tréguas se justificam, porque este império se aumentará às perdas de V. Magestade, dos seus súbitos e dos seus domínios (translation: Antunes). existence of ideas about empire within the Republic's intellectual landscape that can be linked to specific political thinkers or specific imperial moments. ${ }^{5}$

This introduction and thematic issue move beyond the study of Republican thought and imperial moments to demonstrate the existence of a Dutch empire that, like all other empires in Western Europe, served the goals, interests and needs of the central state, the local (metropolitan and colonial) elites and the common man. This empire is depicted here not only as a trading enterprise, as is often claimed, but, like all other empires, a discontinued territorially expanding state that faced challenges regarding sovereignty, subjection and belonging across the globe. I consequently suggest changing the paradigm from a binary narrative about the commercial companies into a diverse, multi-factorial, diachronic and holistic interpretation of the genesis and development of the Dutch empire, with a clear emphasis on the multiplicity of actors who not only created, participated in and developed, but also became the empire.

5 Martine J. van Ittersum, Profit and Principle: Hugo Grotius, Natural Rights Theories and the Rise of Dutch Power in the East Indies, 1595-1615 (Leiden 2006); Pepijn Brandon and Karwan Fatah-Black, "For the Reputation and the Respectability of the State": Trade, the Imperial State, Unfree Labor, and Empire in the Dutch Atlantic', in: John Donoghue and Evelyn P. Jennings ed., Building the Atlantic Empires: Unfree Labor and Imperial States in the Political Economy of Capitalism, c. 1500-1914 (Leiden 2015) 84-108. René Koekkoek, Anne-Isabelle Richard and Arthur Weststeijn, 'Visions of Dutch Empire - Towards a Long-Term Global Perspective', Bijdragen en Mededelingen Betreffende de Geschiedenis der Nederlanden 132.2 (2017) 79-96; Arthur Weststeijn, 'Provincializing Grotius - International Law and Empire in a Seventeenth-Century Malay Mirror', in: Martti Koskenniemi, Walter Rech and Manuel Jimenez Fonseca ed., International Law and Empire: Historical Explorations (Oxford 2017) 21-38. 


\section{European Maritime Expansion and Early Modern Empire-Building}

The developing Iberian empires created the first matrix of Western European exploitation overseas and, as such, were characterized by four specific features: territorial conquest complementary to maritime expansion, economic exploitation of newly acquired territories, control of mobility to and within the empire, and localized civil and religious administration. The historiographical focus on the actions of the VOC and the WIC as primarily trading enterprises has seriously overlooked the companies' role in the above-mentioned features of Early Modern empire-building.

Dutch maritime expansion has been contextualized as a reaction to Iberian dominance in Europe and overseas. At the time, contemporary intellectuals considered this expansion a threat to the model of universal monarchical rule that safeguarded Iberian monarchs' sole and divine right to exploit, dominate and enforce an empire outside Europe (co-joining imperium and dominium), with the Dutch offering as an alternative a particularist model of expansion where, even if territorial conquests could be claimed as part of a king's sovereign realm, this was not so by divine right, and nor were the seas subject to anyone's sovereignty (as reflected in the discussion on Mare Clausum vs Mare Liberum). ${ }^{6}$ The striking differences between the Iberian and Dutch modes of conceptualizing

6 C.H. Alexandrowicz, 'Freitas versus Grotius', in: David Armitage ed., Theories of Empire, 1450-1800 (Farnham 1998) 239-260; Franz Bosbach, 'The European Debate on Universal Monarchy', in: David Armitage ed., Theories of Empire, 1450-180o (Farnham 1998) 81-98. 'empire' have produced a historiography tending to emphasize the particularities of each empire that determined the different colonial trajectories.

When zooming in on the practices of empire-building, universal or particularist alike, a general framework can be discerned. From the state's perspective, sovereignty was a matter for the central state (kings, queens, parliaments or the States General) and enacted by defining jurisdictions (over territory and peoples), and thus delineating physical and social borders. ${ }^{7}$ The administration of sovereignty, by contrast, was adjudicated by the central state to its social domestic partners. These were generally the elites, who were given the opportunity to serve the central state in managing and exploiting the empire and, conversely, participating in the governing of the central state, and concomitantly the empire, through multiple mechanisms of negotiation. The elites thus became, according to Regina Grafe and Alejandra Irigoin, 'stakeholders of empire. ${ }^{8}$ As well as constituting the empire's bureaucratic bodies, these elites, more importantly, became the catalysts for the economic exploitation of the resources of empires through direct trade, taxation and appropriation of a regime of property rights (public and private). Since property rights needed enforcement, judicial bodies were created to fulfil that role, while simultaneously becoming enforcers of social practices and thus governing bodies in their own right. Inextricably, they

7 Tamar Herzog, Frontiers of Possession: Spain and Portugal in Europe and the Americas (Cambridge MA 2015).

8 Regina Grafe and Alejandra Irigoin, 'A Stakeholder Empire: The Political Economy of Spanish Imperial Rule in America, The Economic History Review 65.2 (2012) 6o9-651. 
were linked to matters of law and morality directly co-dependent on the management of religious affairs.

From the perspective of the individual, regardless of social provenance, the empire was a source of employment, with relatively high and secure wages, often paid in coin or kind. Wages could also be complemented with steady parallel sources of income (mostly through illegal activities) that resulted in unusual opportunities for accumulating wealth and consequent social upward mobility. The latter often translated into a shortening of the distance between state and subjects, as well as between different social groups. Individuals also benefited from the economic gains of empires, financially because they presented new opportunities for short- and long-term investments, socially because they offered new titles and products that shaped tastes and consumption patterns, and intellectually because they created opportunities for access to new sources of knowledge. ${ }^{9}$

With regard to the Dutch maritime expansion and subsequent constitution of an empire, many of these features have previously been ignored, underplayed or overshadowed by alternative interpretations of the country's colonial trajectory. In my view, this has been because the focus in the case of Dutch maritime

9 Maxine Berg and Helen Clifford ed., Consumers and Luxury: Consumer Culture in Europe, 16501850 (Manchester 1999); C.A. Davids, 'On Machines, Self-Organization and the Global Travelling of Knowledge, c. 1500-1900', Isis. Current Bibliography of the History of Science and Its Cultural Influences 106.4 (2015) 866-874; Erik Odegard, Colonial Careers: Johan Maurits, Rijckloff Volckertsz. van Goens and Career-Making in the Seventeenth-Century Dutch Empire (unpublished $\mathrm{PhD}$ dissertation, Leiden University, 2018). expansion has been on the societal consensus that arose with the mode of economic exploitation of resources, i.e. the commercial companies, rather than on the practice of empire-building as a holistic, diachronic process. I argue that the companies were the means through which the central state (the States General) carved a space of sovereignty for itself that it lacked in the domestic context, dominated as the latter was by shared sovereignty with provincial and urban governments. Through the corporate constitution of the companies, ${ }^{10}$ the States General defined jurisdictions over territories and peoples, offering the administration of those jurisdictions to the VOC and the WIC, whose ability to include metropolitan urban elites in their governance forged a bond of governability and thus dominium over the spaces overseas. Jurisdictional administration in the sovereign's name was furthered by targeting economic extraction through means of trade, taxation and the imposition of a specific regime of property rights for all those serving, living in and passing through the companies' territorial possessions. Enforced by a system of courts, limited by the demands of religious jurisdictions and supervised by the need for regular reporting to the sovereign through requests for charter renewals, the companies were instruments of empire-building.

Perpetuating a binary narrative (VOC/ WIC, East/West) when analysing the Early Modern Dutch maritime expansion overseas obscures and neglects the

10 William Pettigrew, 'Corporate Constitutionalism and the Dialogue between the Global and Local in Seventeenth-Century English History', Itinerario 39.2 (2015) 487-501. 


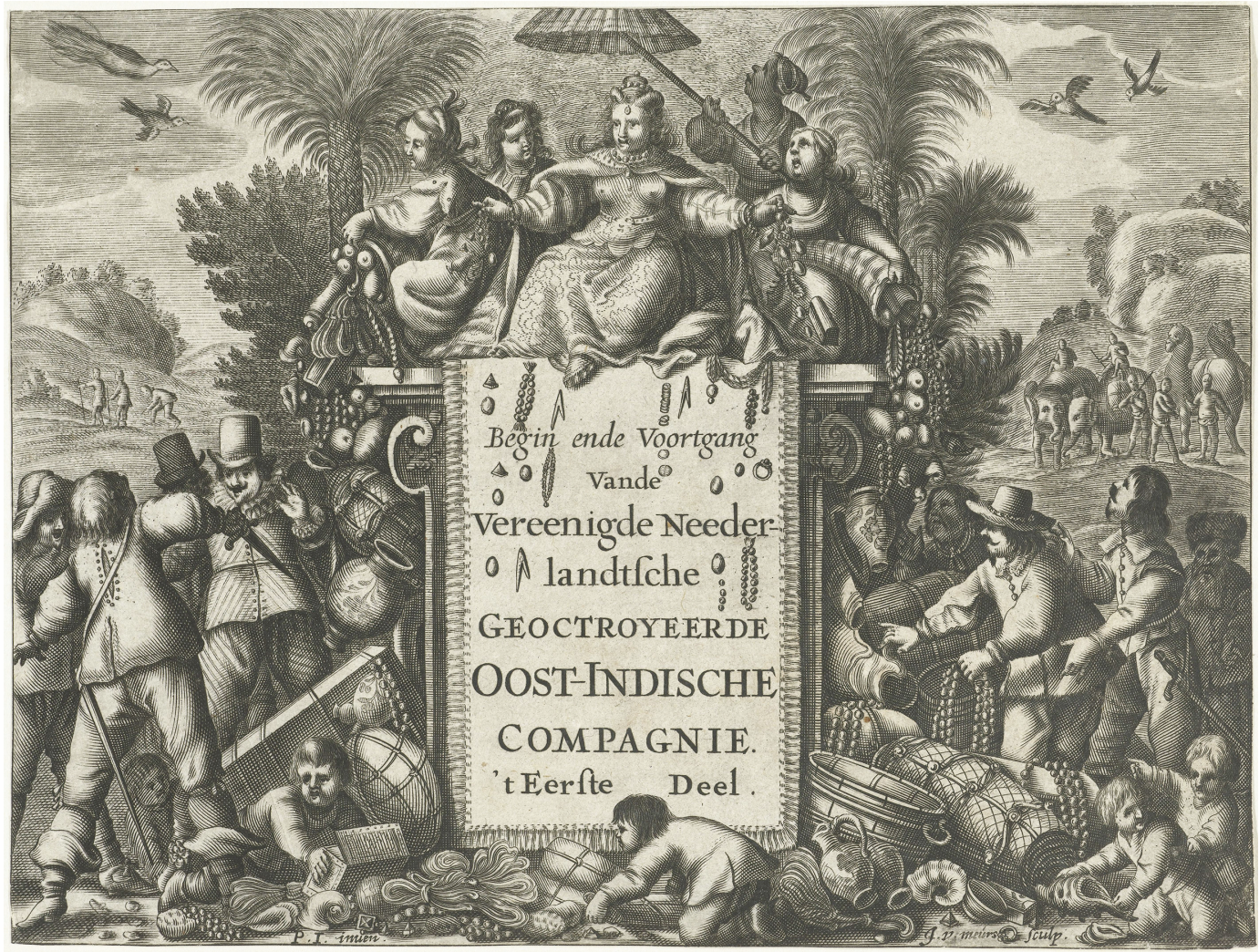

Allegory print in I. Commelin, Begin ende voortgangh van de Vereenighde Nederlantsche Geoctroyeerde Oost-Indische Compagnie, 1646, by Jacob van Meurs, 1644-1646.

Rijksmuseum Amsterdam

importance of the features of empires actually encapsulated by this expansion. In this sense, we urgently need to change the paradigm of the historical research and narrative of the Dutch maritime expansion during the Golden Age by focusing on the features of empires that can be identified in this expansion, rather than on the companies as corporate institutions. This change of paradigm relies on three avenues of analysis that reflect the Dutch experience and contrast it with the empire matrix developed by its Iberian forerunners: 1) analysing the relationship between the States General and the companies as more than just a delegation of partial sovereignty; 2) understanding the companies as multi-factorial agents beyond their role as corporate entities, and 3) comprehending the role played by the companies in the Republic and the colonial spaces as an interconnected space of exchange.

\section{The States General and the Companies}

The first change in paradigm demands a closer look at the relationships between the companies and the state, and how both parties used each other to attain, improve and lay claim to different regimes of sovereignty in a way that strengthened 
the States General's position in matters of overseas governance (a position it never attained in the Republic itself) and that, albeit not consensual, was never really contested. This avenue of research creates a better comparative understanding of regimes of overseas sovereignty claimed by European expanding empires, based on the acknowledgement that territorial conquest is a consequence of maritime expansion, beyond the theoretical dichotomy between universalist and particularist expansions. ${ }^{11}$

There is a certain consensus that the VOC resulted from a compromise between investors operating in Asia before 1602 (the voorcompagniëen) and the States General, which conceded the charter. Even though some companies in the Republic are known to have disputed the charter's contents by claiming rights to a charter or patent of their own, historians have mostly disregarded these claims or the extent to which these companies tried to fence their rights off from the States General through the courts. ${ }^{12}$ In the case of the WIC, however, consensus was absent from the start, with the opposition arising within the States General itself. Provinces had differing ideas about using a West India Company to explore the Atlantic, with some preferring to keep peace with the King of Spain rather than provoke open warfare in the South Atlantic and the Caribbean. The company's formation

11 Alexandrowicz, 'Freitas versus Grotius', 242; Bosbach, 'The European Debate on Universal Monarchy', 88.

12 The cases of the companies of Isaac le Maire and Olivier van Noort are explored by Kate Ekama in: Courting Conflict: Opposition to the Dutch East and West India Companies (unpublished PhD dissertation, Leiden University, 2018), especially chapter 2. was thus postponed until after the Twelve Years' Truce (1621). Once formed, the WIC witnessed two further occasions of dissent: firstly the successful lobbying by the towns of Hoorn and Enkhuizen to exclude salt exploitation and trade in Punta de Arraya from the charter, ${ }^{13}$ and secondly the refusal by the Atlantic investors and operators to relinquish their infrastructures in the Atlantic without compensation. ${ }^{14}$

Despite this opposition, the companies became the grounds for the affirmation, and possibly centralization, of power by the States General, a relatively weak institution of sovereignty and governance owing to its representative and collegial nature. Before the States General issued the charters in 1602 and 1621 , the right to issue such charters was, like patents, a jurisdictional privilege of urban and provincial governments, on which the sovereignty of the Republic relied in practice. ${ }^{15}$ The States General thus saw maritime expansion and overseas exploration as an opportunity to bring management and governance of the overseas exchanges into its realm of privileges. Since disputing the urban and provincial privileges of issuing charters and patents in the Republic would have provoked great political opposition, the States General assumed the role of chartering institution for the overseas domains. This accredited the States General with a sovereignty that

13 On these lobbying techniques and mechanisms, see Joris van den Tol's contribution in this issue.

14 Stadsarchief Amsterdam, Notariële Archief, 201, 137 .

15 For the powers and jurisdictions of Dutch cities, see: Marjolein 't Hart, 'Cities and Statemaking in the Dutch Republic, 1580-1680', Theory and Society 18.5 (1989) 663-687, therein 677 . 
it scarcely had within the context of the United Provinces.

This outsourcing of sovereignty rights to the VOC and the WIC, in what could be perceived as a way of granting full sovereign status to the companies, ${ }^{16}$ is essentially comparable to the means and mechanisms of sovereignty that Iberian kings delegated to their viceroys, governors, charitable institutions and the Church. Iberian historiography associates this sharing and distributing of power and sovereignty among social allies in Europe with the state's increasing efficiency in controlling overseas territories. This is reflected in a polycentrism (social and geographic) that resulted, on the one hand, from a weak state unable to control its overseas domains and subjects and, on the other hand, from a cleaver mechanism used to control European subjects engaged in colonial affairs, while the monarchies' actions in the colonial sphere assume a form of representational royal power. ${ }^{17}$ While the States General acted no differently from the Iberian kings when decentralizing sovereignty, the former was stronger because it presumed itself to have the power to adjudicate sovereignty to the companies, and those same companies then become enforcers of the States General's power and design in the colonies.

16 Philip J. Stern, The Company-State: Corporate Sovereignty and the Early Modern Foundations of the British Empire in India (New York 2011); Pettigrew, 'Corporate Constitutionalism', 493.

17 Pedro Cardim, Tamar Herzog, José Javier Ruiz Ibáñez and Gaetano Sabatini ed., Polycentric Monarchies. How did Early Modern Spain and Portugal Achieve and Maintain a Global Hegemony? (London 2014) especially part 1: Spaces of Integration.
If the motives behind the States General's strategy to use the companies to control overseas territories, on the one hand, and affirm its sovereignty in the Republic itself, on the other hand, seem part and parcel of a complex discussion of the possible ways in which colonial expansion could be used to strengthen the metropolitan European state (as has been argued for the Iberian cases), the way the companies were used in the European context for the gain and glory of the States General were extraordinary. The States General was able to enrol the companies' men and ships, at various moments in time, to participate in naval warfare in European waters in matters not directly concerning the companies. ${ }^{18}$ This ability to call on, use and bring under the command of the generality assets that were private in nature raises the question of whether the Dutch companies were company states, or whether the state was becoming a company with the ability to resort to private means of warfare to manage and monopolize the companies' and its own violence. ${ }^{19}$

\section{From Corporate Tales to Inclusive Spheres}

The second paradigm needing to change is that of the prevalent mono-subject approach to the companies as corporate commercial identities that economically exploited newly acquired territories.

18 Erik Odegard, 'The Sixth Admiralty: The Dutch East India Company and the Military Revolution at Sea, c. 1639-1667', International Journal of Maritime History 26.4 (2014) 669-684.

19 Ibidem, 670; Stern, The Company-State, 38. 
Instead we should adopt a multi-factorial approach to the companies as territorially expanding enterprises in the business of building an empire. An analysis of the fiscal, administrative and religious regimes prevailing in the Dutch possessions in the Atlantic and Asia yields numerous common features in the governance of territory and peoples, regardless of local variations or specificities. In this sense, and even though the two companies were devoted to two diverse geographical spaces, they used similar mechanisms of localized administration (civil and religious) to govern their territories and consequently an empire.

In terms of economic exploitation, the VOC and the WIC are seen, on the one hand, as opportunities for corporate investment through shareholding in Europe and, on the other hand, as trading ventures, and also, in a few cases and specific chronologies, as mechanisms of warfare against competitors. This idea of the companies as investment and trading enterprises is rooted in the assumption that the companies were mostly corporate entities, with the VOC, the first of its kind, being geared to maximizing profit in the two leading economic sectors of the time: trade and shipping. ${ }^{20}$ In this sense, and following this logic, there is little to suggest that the Dutch maritime expansion attained and organized by the companies was actually an empire. Evidence from the fiscal, administrative and religious regimes deployed by the companies, however, substantiates different insights.

20 Gelderblom et al., 'The Formative Years', 1071; Gaastra, Geschiedenis van de VOC, 58; Henk den Heijer, Goud, Ivoor en Slaven (Zutphen 1997).
The VOC entered the Indian Ocean with a clear mandate to acquire Asian luxuries for trading in the markets of the Dutch Republic. The VOC's task was twofold: on the one hand, to pursue the trading routes necessary for acquiring Asian products that were marketable in the Republic and, on the other hand and if possible, to curb Portuguese competition either by capturing Portuguese fleets in Asian waters or penetrating, peacefully or violently, the routes where the Portuguese got their supplies. ${ }^{21}$ To achieve these goals, the VOC was soon forced to attack the Portuguese possessions in the East and to initiate a campaign to conquer ports, forts and territories from the Indian Ocean to the Far East. While this campaign was characterized by varying degrees of success, by the 1660 os the VOC had delivered a severe blow to the Estado da Índia and Amsterdam became the world market for Asian products.

While traditional historiography acknowledges the conquering aims of the VOC, these aims appear subjected to the idea that conquest was simply a means to penetrate existing trading routes in the hands of the Portuguese and their local allies rather than a deliberate plan to take over specific spaces in Asia. Even if there is merit in this argument, the fact that the VOC took over the fiscal and commercial organization of the places conquered from the Portuguese demonstrates that the company was well aware

21 Ernst van Veen, Decay or Defeat? An Inquiry into the Portuguese Decline in Asia, 1580-1645 (Leiden 2000); André Murteira, A navegação portuguesa na Ásia e na rota do Cabo e o corso neerlandês, 1595-1625 (unpublished $\mathrm{PhD}$ dissertation, New University of Lisbon, 2016). 
of perhaps the most crucial element of empire, the opportunity to extract fiscal revenue. Combining trade with taxation on commerce, local production and market transactions provides a glimpse into the company's more ambitious plans. ${ }^{22}$

In the case of the WIC, the company carries the historiographical label of being created primarily as a war mechanism against the Spanish empire. If the WIC was created as an instrument of warfare, which I believe it was, violence at sea, but also on land, was the result to be expected. The issues relating to violence at sea have been fairly well, although not thoroughly, studied, with the famous assault and capture of the silver fleet by Piet Hein or the numerous captures of Portuguese ships from Asia in the South Atlantic being the only cases where historians have analysed the company's practices in depth. ${ }^{23}$ However, the link between maritime and territorial violence becomes lost when historians leave the maritime frontier to examine

22 Tonio Andrade, How Taiwan Became Chinese: Dutch, Spanish, and Han Colonization in the Seventeenth Century (New York 2007); Alicia Schrikker, Dutch and British Colonial Intervention in Sri Lanka, 1780-1815: Expansion and Reform (Leiden 2007); Markus Vink, Encounters on the Opposite Coast: The Dutch East India Company and the Nayaka State of Madurai in the Seventeenth Century (Leiden 2015). Jan Kok (Radboud University Nijmegen) and Alicia Schrikker (Leiden University) have made great progress in processing the information of the Tombo's. Their work remains essential for new insights into the role the VOC played in Asia in general and Ceylon in particular.

23 Ronald Prud'homme van Reine, Admiraal Zilvervloot. Biografie van Piet Hein (Amsterdam 2003); André Murteira, 'O Estado da Índia e as Companhias das Índias Orientais neerlandesa e inglesa no Índico Ocidental, 1600-1635', in: Santiago Martínez Hernández ed., Governo, política e representações do poder no Portugal Habsburgo e nos seus territórios ultramarinos (Lisbon 2011) 177-195. the WIC's intervention in the conquest of the northeastern captaincies of Portuguese Brazil or its desperate struggle to keep the English out of its North American colony of New Netherlands. ${ }^{24}$ The lack of a clear link between these two spheres of violence has caused the correlation between conquests at sea and conquests on land, and how those inform and influence each other, to be overlooked. ${ }^{25}$

If fiscality means economic exploitation of newly conquered territories, it also implies the reality of territorial control over specific spaces and thus over specific peoples. This territorial and human control, often translated into fiscal, judicial and administrative jurisdictions and reflected in the institutionalization of fiscal regimes or court systems, demonstrates that the companies were not merely corporate trading institutions, but also, and perhaps above all, administrators of empire in the name of the States General. Civil and fiscal administration through the institutionalization of multiple and diverse jurisdictions was reinforced by the development of yet another type of jurisdiction, that of the religious congregations. Even if the Dutch Republic was nominally Protestant, many serving the companies or living in their territorial conquests were not. For that reason, the religious congregations competed for space within the Dutch colonial enterprise. The defining of religious borders between Catholics, Jews and Protestants

24 Hermann Wätjen, Das holländische Kolonialreich in Brasilien (Springer 1921); Charles R. Boxer, The Dutch in Brazil, 1624-1654 (London 1957); Jaap Jacobs, New Netherland: A Dutch Colony in Seventeenth-Century America (Leiden 2005).

25 Wieke Vink, Creole Jews: Negotiating Community in Colonial Suriname (Leiden 2010) 24. 


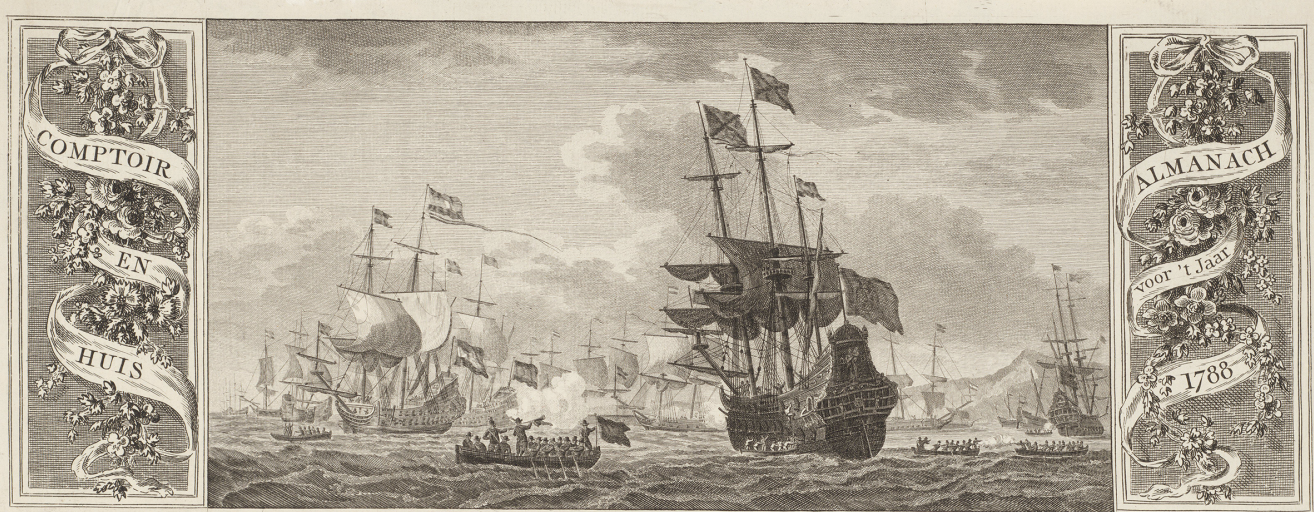

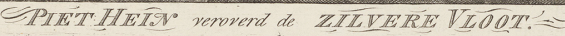

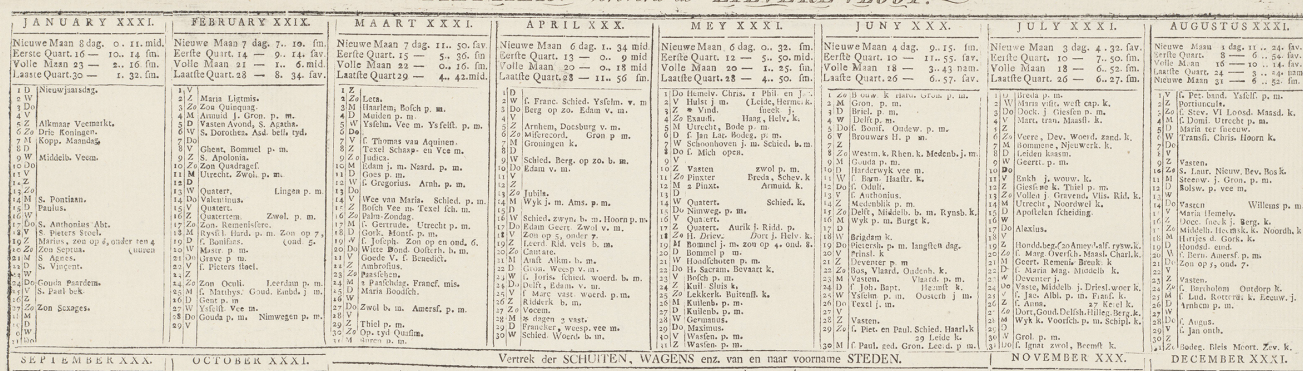

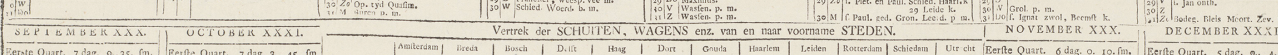

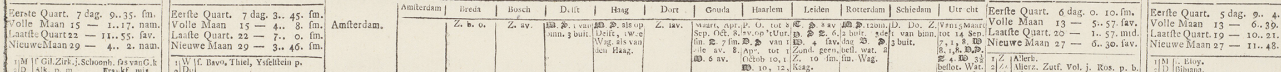

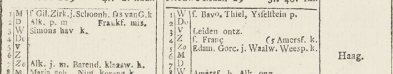

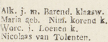

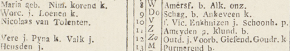

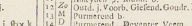

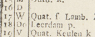

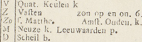

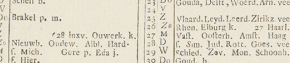

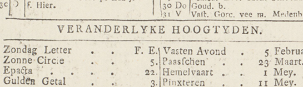

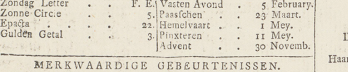

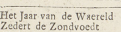

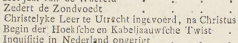

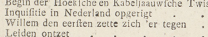

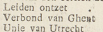

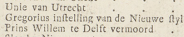

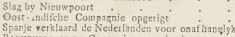

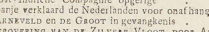

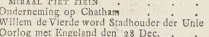

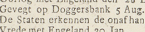

W

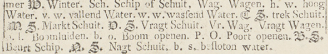

Almanac with the prize of the 'Silver Fleet' by Piet Hein 1628. Anonymous, 1787-1788.

Rijksmuseum Amsterdam 
in Dutch Brazil, along with the institutionalization of Protestantism in Batavia and the multi-religious jurisdictions in Cochin, as also reflected in Suriname and Curaçao, are just a few examples of the role religion played in the Dutch empire, rather than in the policy of the companies as commercial corporations. ${ }^{26}$

\section{From Metropolitan and Colonial Social and Economic Formations to Integrative Social Spheres}

The third paradigm that needs changing is that of the role the companies played in the Republic and overseas. Rather than being seen as two almost separate spheres, the colonial and metropolitan spaces should be regarded as interconnected. On the one hand, because of the existence of socially integrated spheres through the mechanisms made available by existing social networks that operated

26 Jonathan I. Israel and Stuart B. Schwartz, The Expansion of Tolerance in Dutch Brazil (1624-1654) (Amsterdam 2007); D.L. Noorlander, Serving God and Mammon: The Reformed Church and the Dutch West India Company in the Atlantic World, 1621-1674 (unpublished PhD dissertation, Georgetown University, 2011); Alexander Bick, Governing the Free Sea: The Dutch West India Company and Commercial Politics, 1618-1645 (unpublished $\mathrm{PhD}$ dissertation, Princeton University, 2012); Deborah Hammer, Creating an Orderly Society: The Regulation of Marriage and Sex in the Dutch Atlantic World, 1621-1674 (unpublished $\mathrm{PhD}$ dissertation, Columbia University, 2014); Carla van Wamelen, Family life onder de VOC. Een handelscompagnie in huwelijks-en gezinszaken (Hilversum 2014); Jos Gommans, 'South Asian Cosmopolitanism and the Dutch Microcosms in Seventeenth-Century Cochin (Kerala)', in: Cátia Antunes and Jos Gommans ed., Exploring the Dutch Empire: Agents, Networks and Institutions, 16002000 (London 2015) 3-27. within the nexus of the familial system and were able to provide opportunities for career advancement, upward social mobility and effective administration of the territories and spheres within the companies' jurisdictions, regardless of whether the members of those networks were situated in the cities of the Republic or in the colonial spaces. And, on the other hand, because of the development of co-dependencies and exchanges of economic frameworks, the central engine of which was the empire. In this sense, the ships built for the companies, the financial instruments that were created or improved to serve the colonial needs of investors in the Republic and elsewhere, the metropolitan earnings in wholesale and retail centred around the companies' auctions and the regional profits of the colonial logistics all showcase the importance of empire in the overall economic gains of the Dutch Republic.

One of the ways in which spaces for negotiation ensued between the metropolis and the colonies was through the intertwining of social networks in the two spaces. On the one hand, these social networks, often the origin of a specific cursus honorum within the companies' ranks, balanced the specifications of the familial and coreligionist networks, while, on the other hand, they created mechanisms for accommodating political conflict and members' descent. In this sense, factionalism, opposition and the familial state were deployed through the intermediary role that social networks played in establishing and promoting members' social, economic and political success. These social networks accommodated members, both in the colonial spaces and the metropolis, who responded to different 
incentives, but remained co-dependent on and intertwined by relationships of clientelism, patrimonialism and extended family relationships (marriages and baptisms). ${ }^{27}$ The overarching role these social networks played in promoting their members in the metropolis and the colonies resulted in both spaces co-opting the needs, ambitions, problems and solutions of their members, of the network itself, of the company and, ultimately, of the empire.

If social networks played an important role in bridging the gap between metropolitan and colonial spaces, events in the colonies were of crucial importance in the political power play in the Republic. Colonial problems were often used as bargaining chips in the decision-making processes of the companies and States General alike. A complex, but illustrative example is that of the survival of Dutch Brazil. From the start, Dutch Brazil needed metropolitan resources (military, logistic and financial) to survive. The WIC was incapable of negotiating the means needed to keep this colony alive with the States General and the WIC's own chambers. Indeed the colony was often used in metropolitan discussions as a bargaining chip for Dutch participation in various European conflicts and for safeguarding specific economic and commercial priorities to the detriment of the colonial space. ${ }^{28}$ Even after the colony was lost to the Portuguese, Brazil continued to be used as a negotiating weapon in the arena of international relations. It was not until the States General undertook to force the VOC to accept Catholic jurisdictions

27 Odegard, Colonial Careers.

28 Van den Tol, Lobbying in Company. within its possessions in Cochin, São Tomé de Meliapor and Melaka that the Portuguese agreed to compensate the WIC for its losses in Brazil. ${ }^{29}$

The interconnectednesses generated by the Dutch empire extended further to include the metropolitan urbanity. While studies of the VOC and WIC have demonstrated the importance of the companies, mostly as employers and thus as sources of stable income, little research has been conducted into relationships between the outgoing and incoming demands of empire. A few exceptions, however, should be noted. The first of these are the studies of the sectors in the metropolitan economy that developed or grew because of the empire. Although shipping, shipbuilding, financing and insurance are activities that have been broadly addressed in the historiography, they have not sufficiently been brought into a direct relationship with the emergence of a Dutch empire..$^{30}$

29 Cátia Antunes, 'Oost voor West en West voor Oost. Nederlands-Portugese koloniale interactie in de zeventiende eeuw', in: J. Thomas Lindblad and Alicia Schrikker ed., Het verre gezicht. Politieke en culturele relaties tussen Nederland en Azië, Afrika en Amerika. Opstellen aangeboden aan Prof. Dr. Leonard Blussé (Franeker 2014) 35-48.

30 Richard W. Unger, 'Technology and Industrial Organization: Dutch Shipbuilding to 180o', Business History 17.1 (1975) 56-72; Sabine Go, Marine Insurance in the Netherlands, 1600-1870: A Comparative Institutional Approach (Amsterdam 2009); Daniel Strum, The Portuguese Jews and New Christians in the Sugar Trade: Managing Business Overseas - Kinship and Ethnicity Revised (Amsterdam, Porto and Brazil, 15951618) (unpublished PhD dissertation, Hebrew University of Jerusalem, 2009); Jan Lucassen and Richard W. Unger, 'Shipping, Productivity and Economic Growth' in: Richard W. Unger ed., Shipping and Economic Growth, 1350-1850 (Leiden 2011) 1-43; Cátia Antunes and Filipa Ribeiro da Silva, 'Amsterdam Merchants in the Slave Trade and African Commerce, 1580s-167os', Tijdschrift voor Sociale en Economische 


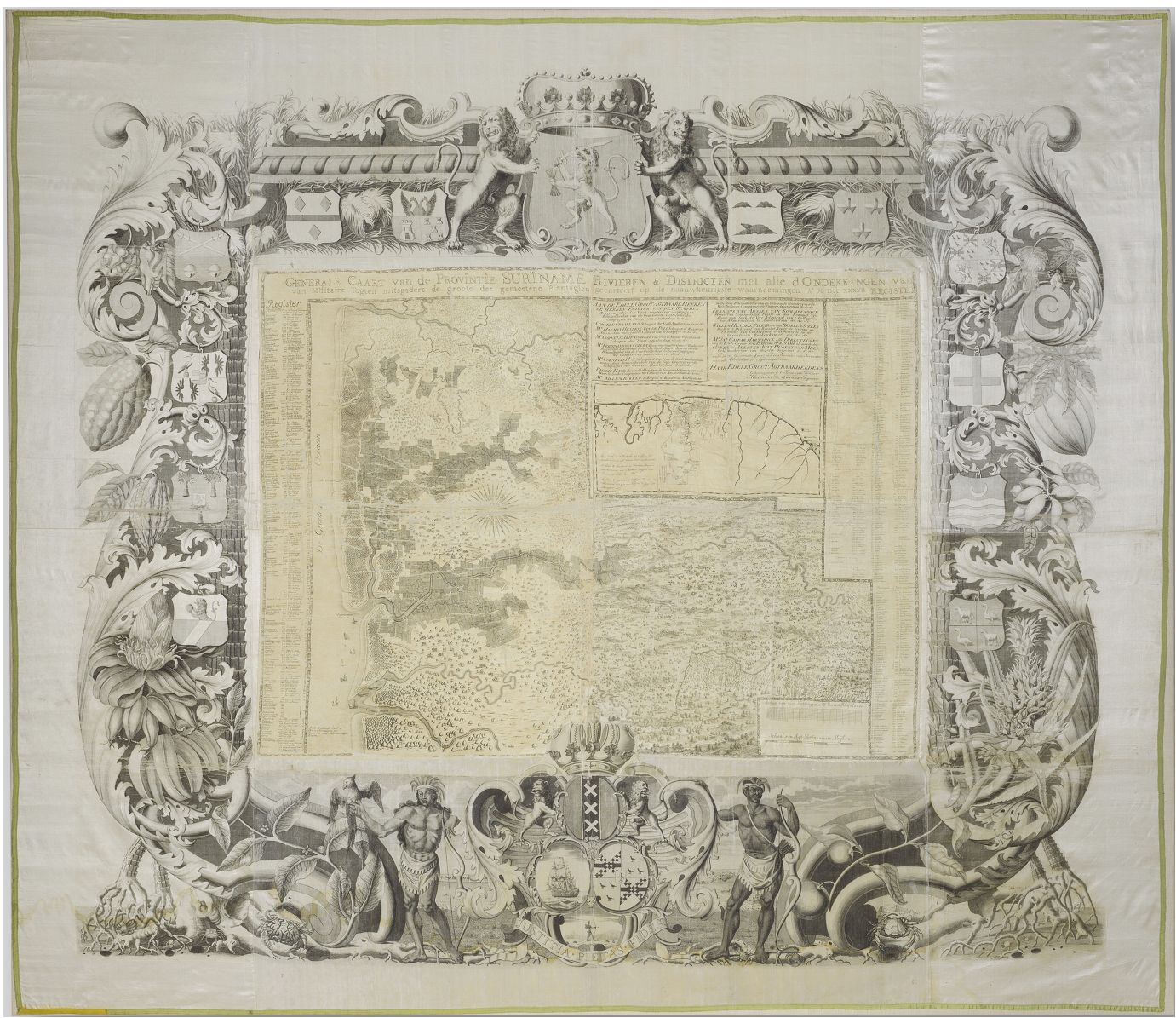

Map of Suriname, by Alexander de Lavaux, 1737 .

Rijksmuseum Amsterdam

The metropolitan urban economies were also the site of company auctions, and while historiography regarding the auctions of colonial products in the Republic is scarce, the regulations prohibiting the companies' directors from bidding for auction lots did not really change the trend whereby markets - not only wholesale,

Geschiedenis 9.4 (2012) 3-30; Bram Hoonhout, 'Subprime plantation mortgages in Suriname, Essequibo and Demerara, 1750-180o. On Manias, Ponzi Processes and Illegal Trade in the Dutch Negotiatie System' (unpublished MA thesis, Leiden University, 2012). but also retail ${ }^{31}$ - were dominated by the companies' management. Cities in the Republic were not, however, the only spaces benefiting from the colonial enterprise. Hinterlands in the coastal, but also interior provinces were also able to share in the profits and localized growth enabled by the companies through subcontracting shipbuilding and repairs, logistics for equipping and provisioning the fleets, as well as from building and maintaining

31 Kristof Glamann, Dutch-Asiatic Trade, 1620-1740 (The Hague, 1981). In this issue, see the article by Karwan Fatah-Black and Mike de Windt. 
infrastructures for serving the colonial fleets. ${ }^{32}$

\section{Thematic Issue}

The avenues of research presented in this introduction result in a broader understanding of what the Dutch empire was and the role the States General, the companies and the metropolitan and colonial societies played in its conceptualization and development. The articles in this issue move from binary narratives of the Dutch companies and their participation in the Atlantic and Indian Ocean trades to diversified tales where colonial history is part of Dutch national history rather than a separate historiographical category. The articles that follow depart from an understanding of the Dutch Republic and empire as interconnected spaces of compromise, where the companies, their employees and the peoples under their dominium negotiated, in different arenas and platforms, to attain social, political and economic advantage.

Kate Ekama analyses the role the High Court (Hoge Raad van Holland, Zeeland en West-Friesland) played in mediating conflicts between the VOC, WIC and multiple actors (subjects of the States General, private companies, foreigners, groups and individuals). Rather than focusing on the conflicts faced by each of the companies individually, she proposes a thematic

\footnotetext{
32 Karwan Fatah-Black and Matthias van Rossum, 'Beyond Profitability: The Dutch Transatlantic Slave Trade and its Economic Impact', Slavery \& Abolition 36.1 (2015) 63-83; Gerhard de Kok, 'Cursed Capital: The Economic Impact of the Transatlantic Slave Trade on Walcheren around 1770', Tijdschrift voor Sociale en Economische Geschiedenis 13.3 (2016) 1-27.
}

understanding, and thus commonalities, of the conflicts that both companies faced. In the specific case of 'Taking the companies to court', she stresses the importance of individual and collective wage-claiming in the Republic through the companies, while also underlining the importance of labour disputes in negotiating mobility, spaces and perceptions of empire within a Republican nexus.

Staging overseas conflicts in the Republican setting was not a matter only for the High Court, but also for other actors in the political sphere. The interconnectedness and exchanges between the different colonial actors and the local and regional political spheres in the Republic are analysed by Joris van den Tol in 'Kondschappen. Lobbyen in de zeventiende-eeuwse Republiek'. He demonstrates that political decision-making on colonial affairs was a negotiated process between colonial elites, diverse groups and the various ruling elites in the Netherlands, with the intricacies of this negotiating process ultimately resulting in growing integration between the colonies and the metropolis.

The integration process of colonial and metropolitan affairs is further mirrored in Erik Odegard's 'Agent Overzee. Het principal-agent probleem in de Nederlandse handelscompagnieën'. He suggests that the problems of control and representation that overseas commercial companies faced in the Early Modern period were resolved, in the Dutch case, by an integrative process between social networks that operated in the colonial and the Republican sphere. He stresses the role that patronage and family ties played in the management of the Dutch empire, as reflected in the professional trajectories of colonial employees. 
The interdependencies developed between the Dutch empire and Dutch colonial settings are even more evident when we examine the influence that the companies and their businesses had in metropolitan society. Karwan Fatah-Black and Mike de Windt argue in 'De ontbrekende schakels tussen compagnie en consumptie' that new insights into the wholesale and retail of products imported by the companies show the formation of a social and economic elite directly dependent upon colonial business. This group not only supplied the major Dutch markets, their hinterlands and commercial partners with overseas products, but also operated as bolts in the supply of Asian products to fleets departing for the Atlantic, whereby Dutch markets became essential in the development of a global commodity chain connecting East and West.

The Dutch knowledge and exploitation of empire was not limited, however, to cities and towns in the Republic as Dutch merchants and businessmen were also able to exploit other European empires' resources and transfer knowledge and wealth back to the Republic, where some of those resources were reinvested in the empire. Cátia Antunes, Susana Münch Miranda and João Paulo Salvado argue in 'The Resources of Others' that although this phenomenon was widespread and frequent during the Early Modern period, it was during the eighteenth century that it acquired a bolder participation that resulted in greater profits and equally heavy losses.

The joint effort translated in this thematic issue offers thus a new paradigm for the questioning and understanding of Dutch maritime expansion overseas and consequent territorial conquests in relation to the internal history of the Dutch Republic and contrasting and comparing it to other empires.

\section{Over de auteur}

Prof. Dr. Cátia Antunes is Professor of History of Global Economic Networks: Merchants, Entrepreneurs and Empires at the Institute for History, Leiden University. The Fulbright Program, the Dutch NWO and the European Research Council have generously supported her research. Her current interests include global history, comparative history of empires, early modern maritime history and transnational and transcultural entrepreneurship 1500-1914. E-mail: c.a.p.antunes@hum.leidenuniv.nl 


\section{Amsterdam University Press}

\section{Gezocht: historicus}

\section{Kayleigh Goudsmit}

\section{Jonge Historicus van het Jaar 2017}

Zomaar een greep uit wat geschiedenisstudenten en alumni zoal te horen krijgen over hun studiekeuze:

"Dan wil je zeker leraar worden?"

"Maar daar is toch geen werk in te vinden?" "Had je niet beter toekomst kunnen gaan studeren?”

We moeten af van het beeld dat het zo slecht gaat met de historicus op de arbeidsmarkt. Historici zijn aan het werk in verschillende vakgebieden, in verschillende rollen. Maar altijd met de brede basis die ze vanuit de opleiding hebben meegekregen.

In Gezocht: Historicus vind je ervaringsverhalen en tips van historici werkzaam bij de overheid, in het bedrijfsleven, in de media, als onderzoeker of als middelbare schooldocent, en meer.

Beste historici: het is tijd om werk te maken van geschiedenis.

Gezocht: historicus is het ideale boek voor zowel (aankomende) historici als hun toekomstige werkgevers om inzicht te krijgen in hun toegevoegde waarde op de arbeidsmarkt.

Uitgeverij AUP |T+31 (0)2042000 50

info@aup.nl | bestellingen@aup.nl | www.aup.nl

Volg AUP op facebook \& twitter

twitter.com/AmsterdamUPress

facebook.com/AmsterdamUPress

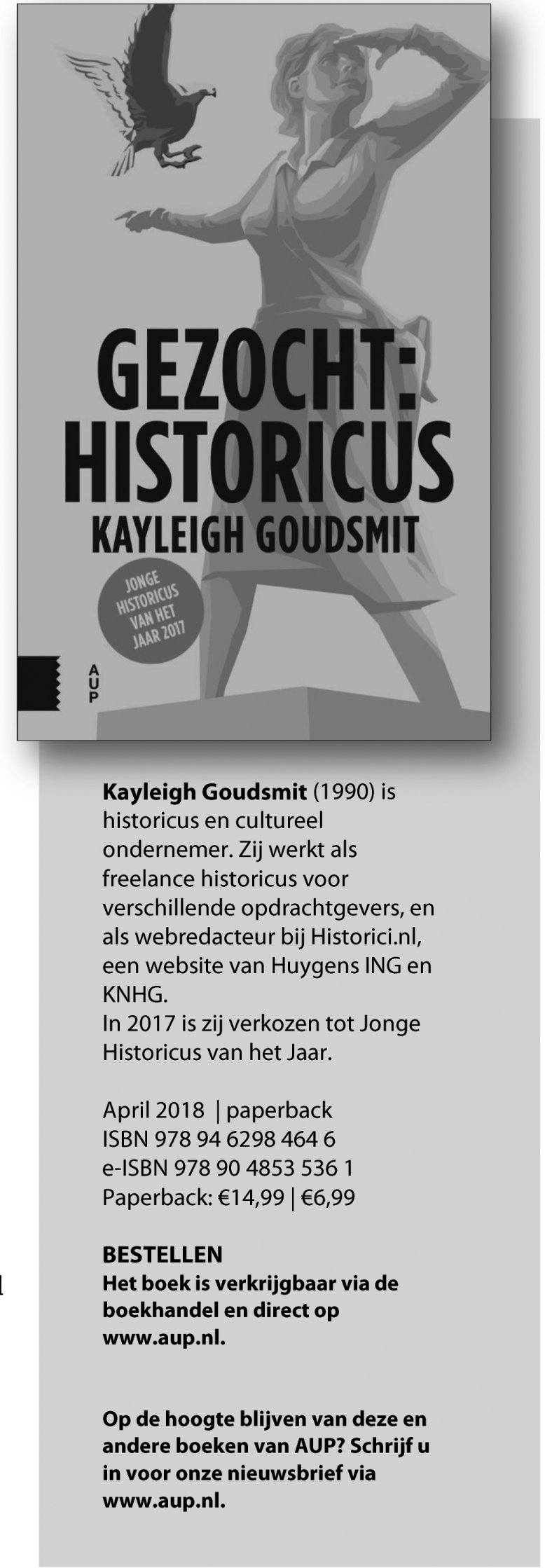

